\title{
ILCEA
}

Revue de l'Institut des langues et cultures

d'Europe, Amérique, Afrique, Asie et Australie

$11 \mid 2009$

Langues \& cultures de spécialité à l'épreuve des

médias

\section{Science for Dummies?}

Media discourse and representations of the "nanorevolution"

\section{Donna Andréolle}

\section{(2) OpenEdition}

\section{Journals}

Édition électronique

URL : http://journals.openedition.org/ilcea/235

DOI : 10.4000/ilcea.235

ISSN : 2101-0609

Éditeur

UGA Éditions/Université Grenoble Alpes

Édition imprimée

ISBN : 978-2-84310-179-3

ISSN : 1639-6073

Référence électronique

Donna Andréolle, «Science for Dummies? », ILCEA [En ligne], 11 | 2009, mis en ligne le 22 avril 2009,

consulté le 08 mars 2021. URL : http://journals.openedition.org/ilcea/235 ; DOI : https://doi.org/

10.4000/ilcea.235

Ce document a été généré automatiquement le 8 mars 2021.

(C) ILCEA 


\title{
Science for Dummies?
}

\author{
Media discourse and representations of the "nanorevolution"
}

\author{
Donna Andréolle
}

1 The ties between science and the media are diverse and operate at multiple levels of discourse and representation: ranging from the highly specialized article to the Hollywood blockbuster, scientific breakthroughs can be presented in didactic, political or socio-economic modes. The culture in which such discourse and representations are conveyed also plays a role not only in how scientific discourse is received but also in how science "talks about itself," what can be termed scientific narrative. In the particular context of American cultural attitudes toward science, the early nineteenth century intelligentsia of the young republic - among whom Thomas Jefferson, William Bartram and Charles William Peale to name but a few - viewed the advancement of scientific knowledge as both utilitarian and political in nature: utilitarian, as it went hand in hand with the expansion of the American "empire of liberty" (Jefferson's expression) and political, as living proof to the old World's scientific community of aristocrats that democracy could breed and sustain intellectual growth in superior ways (Porter, 1986). Combined with this is what scientist and author Stanley Schmidt (1994: 94) terms Americans' "gee-whiz" attitude to scientific and technological innovation, making the United States fundamentally technophile.

2 And yet popular culture representations of science often paint a different picture, if one is to consider, for instance, some recent science fiction movies such as The Matrix, I, Robot or The Island which depict a resolutely technophobic evaluation of the issues raised by artificial intelligence (for the first two) or by breakthroughs in genetics (for the third).

We propose to explore these tensions between technophilia and technophobia, between scientific narrative and science fiction, which can be observed in various media including more specifically in this paper, the written press and the Internet. Mediatized discourse of the nanorevolution is a particularly revealing instance of how different groups, be they specialized journalists, scientists writing for the general public, government agencies or transhumanists, seek to promote the wonders of the 
nanoworld - or on the contrary warn the public of the possible outcome of unregulated enthusiasm for a still relatively unknown field.

Although nanotechnology, for example (see explanation of terms below) is not a totally new concept, dating back in fact to a lecture by Nobel laureate Richard Feynman in 1959 (Amato, 2008: 4), the flurry of writing on subjects related to the nanoworld dates for the most part to the turn of the twenty-first century, two striking examples of which are the special issue of Scientific American in September 2001 and the National Science Foundation report Converging Technologies for Improving Human Performance in June 2002. These two publications illustrate the ambiguities which blur the frontiers between the purely empirical dimensions of the nanosciences (notably in biology and chemistry) and the science fictional extrapolations found in the electronic journal of the transhumanist movement and publications by scientists converted to the transhumanist movement such as K. Eric Drexler and Ray Kurzweil.

\section{Coming to terms with terminology}

There is a certain amount of confusion about what is meant exactly by the word "nanorevolution" and the subcategories of which it is composed; they all, however, originate in the subatomic unit of measure called the nanometer representing one billionth of a meter. Particles of this size were first studied by Einstein in 1905 when he calculated that a sugar molecule measured one nanometer (Stix in SA, 32). The term "nanotechnology" was coined in 1974 by Japanese scientist Norio Taniguchi, who used it to signify "machining with tolerances of less than a micron" (36), but the term has been subject to debate, at least partially because of the use made of it by futurists and transhumanists (to be discussed later in this paper), leading some specialists to associate it with science-fictional extrapolation rather than with "respectable" science. As Gary Stix points out in his article "Little Big Science":

The definition is indeed slippery. Some of nanotechnology isn't nano, dealing instead with structures on the micron scale [...], 1,000 times or more larger than a nanometer. Also, nanotechnology, in many cases, isn't technology. Rather it involves basic research on structures having at least one dimension of about one to several hundred nanometers. (In that sense, Einstein was more a nanoscientist than a technologist.) To add still more to the confusion, some nanotechnology has been around for a while: nano-size carbon black particles (a.k.a. high-tech soot) have gone into tires for 100 years as a reinforcing additive, long before the prefix "nano" ever created a stir. For that matter, a vaccine, which often consists of one or more proteins with nanoscale dimensions, might also qualify. (34)

More recently, in an online brochure entitled Nanotechnology: Big Things from a Tiny World, the National Nanotechnology Initiative ${ }^{1}$ clarified terminology by simply stating that "nanoscience involves research to discover new behavior and properties of materials with dimensions at the nanoscale" whereas "nanotechnology is the way discoveries made at the nanoscale are put to work." (2) Mihail Roco, who oversees nanotechnology at the National Science Foundation, ${ }^{2}$ has given a more restrictive and technical definition of "new" nanotechnology (as distinguished from "old" nanotechnology, i.e. phenomena occurring in the natural world as noted above): it is the emerging field which deals with materials and systems that are no more than 100 nanometers in size, designed through processes that exhibit fundamental control over the physical and chemical attributes of molecular-scale structures that can be 
combined to form larger structures (Stix, 34). This definition of nanotechnology is also now termed "nanosciences and engineering".

7 Last but not least, another term closely associated with the nanorevolution is the expression "converging technologies" made famous by the likes of K. Eric Drexler in his 1986 work Engines of Creation: The Coming Era of Nanotechnology, and later developed by the National Science Foundation in its 2002 report Converging Technologies for Improving Human Performance. Here the idea is that a new holistic approach to science $^{3}$ - as opposed to the currently fragmented, highly specialized approach - will allow to combine (or converge) the four important fields of nanotechnology, biotechnology, information technologies and cognitive sciences to innovate in medicine, education, communications and national security. The definition given in the executive summary of the NSF report is as follows:

The phrase "convergent technologies" refers to the synergistic combination of four major "NBIC" (nano-bio-info-cogno) provinces of science and technology, each of which is currently progressing at a rapid rate: (a) nanoscience and nanotechnology; (b) biotechnology and biomedicine, including genetic engineering; (c) information technology, including advanced computing and communications; (d) cognitive science, including cognitive neuroscience. (2002: ix)

8 It is in the domain of converging technologies that extrapolation is the greatest (and one could say, the most far-fetched) and it is estimated that none of the research objectives related to them will be achievable for up to 20 years at the earliest (Editorial, $S A, 2001$ 8). This has not, however, prevented the American government from quadrupling funds earmarked for nanotechnology research in the past 10 years.

\section{The nanoworld: Seeing is believing}

The basic challenge for all things nano resides in making subatomic objects "visible" to the viewer's eye; this was first achieved, technically speaking, in 1981 when Gerd Binnig and Heinrich Rohrer created the scanning tunneling microscope (STM) which could image individual atoms, marking the beginning of the revolution in nanosciences because it led to other "scanning probe devices" used to fabricate nanostructures (Whitesides \& Love in SA, 2001: 44). But to attract the funding necessary for discoveries of the future in the obscure fields of mesoscale materials engineering, researchers had to capture and hold public attention, in particular that of lawmakers who hold the research purse strings. In the words of Duncan Moore, a White House official who worked on President Clinton's nanotechnology initiative, "[scientists] need to come up with new, exciting, cutting-edge, at-the-frontier things in order to convince the budget- and policy-making apparatus to give more money." (in Stix, 2001:32)

\section{Political visibility: a few figures}

Convinced, then, that the United States should be the global leader in nanotechnology developments for both political and economic reasons, the Clinton administration made mastering breakthroughs in the realm of nanosciences and engineering a top priority for the $21^{\text {st }}$ century. The availability of large sums of federal funding dedicated to this research immediately produced an exponential increase in the number of research projects containing the keyword "nanotechnology" or other nano-related fields. According to Jim Thomas in his article entitled "Future Perfect?" (The Ecologist, 
May 2003), there are three key domains to measure the speed with which nanotechnology research has expanded:

1. The number of patents filed and granted: in 1980 there were 60 patents filed containing the term "nano"; in 2001 there were 445, the majority of which were filed by the U.S. Army.

2. The occurrence of the keyword "nano" in peer-related scientific publications: in 1987 about 200 references to nanotechnology could be found; in 2001, about 7,700; in the first 6 months of 2002, over 6,000. Another phenomenon can be noted here: references to nanotechnology have surpassed the realm of the specialized discourse of scientific publications, occupying a central place in the "vulgarized" science press and in the economic press since at least the year 2000. Even the daily newspaper USA Today has had a column dedicated to the latest nanotechnology news since 2001. To update this information briefly, the keyword search "nanotechnology" produces, in the Library of Congress catalogue, 148 specialized works in 2006, 110 in 2007 and 75 for the first six months of 2008.

3. The public funding devoted to the field: The Clinton administration initiatives resulted in massive interest in nano research, with a budget of 463 million dollars in 2001, 600 million in 2002 and 710 million in 2003; the European Union followed suit and in 2006 devoted one billion dollars to nanotechnology developments. ${ }^{4}$ (Thomas, 33)

11 To sum up here, then, it can be said that the nanorevolution has benefited, in the scientific realm, from the outpouring of federal money to support research thanks to the media attention nanosciences received in the 1980s, notably via Drexler's Engines of Creation and through efforts to educate the public on the developments in the extremely erudite field of quantum physics. The government itself, through the National Nanotechnology Initiative, has created electronic brochures to explain the benefits of nanotechnology applications and products in everyday objects such as sunglasses, baseball bats or flat-screen TVs, while emphasizing the future role of nanoscale production in the obtaining of clean, secure and affordable energy, new medical devices and drugs to treat illnesses like cancer more efficiently, or low-cost filters to provide clean drinking water. (Big Things from a Tiny World, undated: 1)

\section{The discourse of scientific visibility}

It is interesting to contrast and compare how two different publications seek to present and represent the nanorevolution. For this reason we have chosen the special issue of Scientific American (Special Issue, September 2001) and the National Science Foundation report (2002) because, although they would appear to serve the same didactic purpose, they target different reading publics: the first aiming at a wide readership of nonspecialists interested in scientific advances; the second designed to convince American lawmakers to allocate funds for further research in nanotechnology without providing immediate results.

13 The first observation is that each document uses, alternatively, four distinct types of discourse: specialized scientific discourse; pseudo-scientific discourse; economic or commercially-oriented discourse; science fictional discourse. This unique blend of varying degrees of scientific narrative is characteristic of the nanorevolution, perhaps due to its introduction into the popular culture by Engines of Creation which combines technical explanations, industrial forecasts and futuristic scenarios of immortality and truly intelligent artificial intelligence. 
eed, more generally speaking, a nanotechnology keyword search on the ProQuest database at the Library of Congress for instance produces a large array of publications:

- specialized or academic journals such as The Journal of Medicine or Nature;

- semi-specialized (or partially vulgarized) magazines such as The Ecologist or Scientific American;

- pseudo-scientific periodicals (because their content is usually at best questioned and at worst denounced by academics or scientists in the field) such as The Futurist, The Journal of Evolution and Technology (official publication of the Institute for Ethics and Emerging Technologies, linked to the World Transhumanist Association) and electronic "nanozines" like Nanotechnology Magazine; and pseudo-scientific books such as Drexler's Engines of Creation, or Ray Kurzweil's The Singularity is Near: When Humans Transcend Biology and The Age of Spiritual Machines. ${ }^{5}$

- articles in the economic press, for instance a series of pieces in Business Week which examine the commercial applications in the cosmetics industry (l'Oréal), in computers (IBM), in chemicals (Dow Industries), etc.

If we first look at the composition of the special issue of Scientific American, the editorial choice is an eclectic one, with contributions ranging from Nobel prize-winner Richard Smalley to futurist K. Eric Drexler, and assorted pieces by specialized journalists like Gary Stix quoted earlier. Quantitatively speaking, there are four articles written by scientists in the fields of biology, medicine and chemistry; two "framing" articles ("Little Big Science" and "Nanobot Construction Crews") by specialized journalists (general information that supplies a frame of reference for understanding the more technical contributions) and two articles "Machine-Phase Nanotechnology" and "Shamans of the Small" that discuss extrapolation, one by Drexler who presents the transhumanist vision of nanotechnology and one by journalist (and occasional sci-fi author) Graham Collins on new trends in science fiction.

The most striking aspect of this collection of articles is the didactic tone of the scientific pieces, which mix highly technical explanations (such as dip-pen lithography or quantum dot assembly) with colloquial expressions, intertextual references to the popular culture or comparisons with everyday objects. For instance, the lead article is entitled "Little Big Science," an intertextual reference to the movie Little Big Man, while the subtitle adopts a casual tone: "Nanotechnology is all the rage. But what the heck is it?" In the article written by chemists George Whitesides \& J. Christopher Love, "The Art of Building Small," dip-pen lithography which operates at the subatomic level to "push molecules around" is likened to "a goose-feather pen." (44) The same method is described a second time using a slightly different metaphor: "such devices probe materials in the same way an old-fashioned phonograph reads the grooves in a record by dragging a sharp point over the surface and detecting the resulting deflections." (46) The article by Paul Alivisatos, nanoparticle specialist at UC Berkeley ("Less is More in Medicine") also chooses a reference to popular American movie culture to introduce his explanation of nano-breakthroughs in medicine:

The 1966 film Fantastic Voyage treated movie-goers to a bold vision of nanotechnology applied to medicine: through mysterious means, an intrepid team of doctors and their high-tech submarine were shrunk to minute size so they could travel through the bloodstream of an injured patient and remove a life-threatening blood clot in his brain. [...]. The emerging [nano]technologies may not be as photogenic as a platelet-sized Raquel Welch blasting away at a clot with a laser- 
beam, but they are every bit as dramatic because, in contrast, the benefits they offer to patients and researchers are real. (67) movie of the pre-special effects era may also serve another more political purpose: that of playing down the potentially hazardous aspects of introducing artificial nanoparticles into the human body, which leads us to another common theme used throughout literature on nanotechnology: it is "natural" because models exist in the natural world. The stakes are obviously the highest in medicine where research centers on fundamental changes in drugs, disease diagnosis or tissue and limb repair (i.e. invasive procedures). Again we can quote from Alivisatos on this point:

All of biology is arguably a form of nanotechnology. After all, even the most complicated creature is made up of tiny cells, which themselves are constructed of nanoscale building blocks: proteins, lipids, nucleic acids and other complex biological molecules. But by convention the term "nanotechnology" is usually restricted to artificial constructions made, say, from semiconductors, metals, plastic or glass. A few inorganic structures of nanometer scale [...] have already been commercialized.

Nature itself provides a beautiful illustration of the usefulness of such inorganic crystals in a biological context: humble magnetotactic (magnetic-sensitive) bacteria. (2001: 68)

The language used here minimizes the possibly objectionable notion of putting "artificial constructions" into the body with such expressions as "after all", "even the most complicated creature" or the "humble bacteria", and by maintaining a running comparison between nanotechnology and nature: "All of biology is a form of nanotechnology"; biological molecules are "nanoscale building blocks"; and "nature itself" provides the demonstration of how manufactured inorganic crystals are useful "in a biological context." Surprisingly, groups that are so adamantly active in blocking the spread of genetically modified organisms have been slow to alert the public to the dangers of uncontrolled nanotechnology; so far, the only real industry to have suffered from negative publicity in the domain is L'Oréal in 2006 for having revealed its use of nanosomes in its skin cream RevitaLift. ${ }^{6}$ Curiously enough, the article which raises this issue in no uncertain terms is the one by K. Eric Drexler, "Machine-Phase Nanotechnology", which ends with the warning: "But the challenge of preventing abuse - the exploitation of this technology by aggressive governments, terrorist groups or even individuals for their own purposes - still looms large. [...] The advance toward molecular nanotechnology highlights the urgency in finding effective ways to manage emerging technologies that are powerful, valuable and open to misuse." (75)

\section{Government 'Newspeak': Putting spin on nanotechnology}

In contrast to Scientific American, the National Science Foundation report Converging Technologies for Improving Human Performance published in June 2002 serves a more openly political purpose, since its primary reading target is the elected members of the U.S. Congress - that is, those who appropriate funds to the agencies and coordinating bodies involved in nanotechnology research. It is doubtful that Congressmen possess any personal specialized knowledge on the actual subject of nanoscale applications in biology, medicine and quantum physics; and unfortunately it is a well-known fact that they often vote on bills which they have not actually read. This does not, however, exonerate groups using federal money from exhaustive, technical reports which 
address the Congress directly and which seek to maintain government support of ongoing projects.

This is stated in no uncertain terms, for instance, in the framing statement by M. Roco \& W.S. Bainbridge:

New organizational structures and management principles based on fast, reliable communication of needed information will vastly increase the effectiveness of administrators in business, education, and government. Average persons, as well as policymakers, will have a vastly improved awareness of the cognitive, social, and biological forces operating their lives, enabling far better adjustment, creativity, and daily decision making. ( 5 , my italics)

This statement reveals the underlying cultural attitudes of the "useful" science approach so typical of the American vision, already obvious in the title of the report, "for improving human performance" (as opposed, for example, to "for improving the human condition"). The objectives are speed and reliability: emphasis is placed on obtaining results in specific industrial niches, and on convincing lawmakers that the return on investment of federal dollars is imminent; it can be noted that it is no accident that the report is a co-publication of the National Science Foundation and the Department of Commerce.

The report addresses the different fields in which the American government desires to maintain a cutting edge, with the contributions divided into six major categories and each theme then subdivided into two distinct parts, statements and visionary projects:

- Motivation and Outlook (deals with political, economic and scientific stakes of NBIC and government strategies to achieve leadership in nanotechnology);

- Expanding Human Cognition and Communication (includes certain societal issues such as the link between brain enhancement and new forms of crime control);

- Improving Health and Physical Capabilities (the accent is on prolonging life in better conditions and overcoming certain handicaps such as blindness or paralysis);

- Enhancing Group and Societal Outcomes (improving the brain to make human production more efficient; includes considerations on environmental issues);

- National Security (presents projects on how to create the army of the future);

- Unifying Science and Education (new concepts in education including the use of converging technologies for distance-teaching with avatars).

Again, a quick glance at the formulations here demonstrates the importance being placed on action - expanding, improving, enhancing, unifying - and on results (capabilities, outcomes and security).

Although this report continues to be available online, which could lead us to conclude that it aims at informing the general public about government action in these fields, the style, contrary to the Scientific American articles, is highly technical and typical of bureaucratic rhetoric, making it inaccessible to the layman. In the "statement" sections such discourse consists in an increased number of noun clusters, (for example "human performance augmentation strategies" (page 102), "silicon integration electronics technology" (page 120) or "nano-bio-info-cogno human machine interfaces (page 122), use of the passive ("human tissues may be evaluated this way" (page 179), "solved structures must be placed in an appropriate genomic context" (page 197) and a preference for Latinate verbs ('ameliorate' instead of 'improve' for instance), normally associated with specialized scientific publications, especially since it carries with it the 
impression that the author is distancing him/herself from the object of study. Here is an example from the theme summary of the National Security section:

Automation technology (including miniaturization of sensing, augmented computation and memory, and augmented software capability) will enable us to replace pilots, either fully autonomously or with pilot-in-the-loop, in many dangerous warfighting missions. The uninhabited air vehicle will have an artificial brain that can emulate a skillful fighter pilot in the performance of its missions. Tasks such as take-off, navigation, situation awareness, target identification, and safe return landing will be done autonomously, with the possible exception of circumstances requiring strategic or firing decisions. Without the human g-force constraint and the weight of human physical support equipment (oxygen, ejection system, armor, etc.), the planes will be more maneuverable. Tanks, submarines, and other combat vehicles will experience similar benefits. (328)

In passing we can point out that a reversal has taken place in this passage: the inanimate objects, i.e. the "uninhabited air vehicle" (line 4 ) and the "tanks, submarines and other combat vehicles" (lines 10-11) become the subjects of sentences in the active voice ("can emulate a ... pilot"/ "will experience similar benefits" (line 4; line 10). This is in keeping with the predominant double metaphor, used throughout the Converging Technologies report, that of the human body as a machine with replaceable parts on the one hand and of the truly intelligent (and superior-to-the-human) machine on the other.

A completely different tone and style, however, are to be observed in the subsections called "visionary projects." Examples of this are articles such as "Socio-tech... the Predictive Science of Societal Behavior" which reminds the reader of the concept of "pre-crime" in The Minority Report; or "Artificial Brains and Natural Intelligence" which relies on Kurzweil's notion of reverse engineering explained below.

In these contributions, hypothesizing about presently unimaginable objects or technologies naturally leads the respective authors to leave the realm of scientific reality to explore the world of science-fictional extrapolation. This explains why the intertextual references to science fiction novels or movies are used to enable the reader to understand the type of breakthrough being discussed. Such is the case, for instance, in the following passage which seeks to explain Ray Kurzweil's theory of "reverse engineering"' in simpler terms:

Imagine that the brain is fully understood, and therefore the mechanisms and data structures for knowledge, personality, character traits, habits, and so on are known. Imagine further that, for an individual, the data describing that person's knowledge, personality, and so forth, could be extracted from his brain. In that case, his mind could be "run" on different hardware, just as old video games are today run in emulation on faster processors. This, of course, raises lots of questions. What is it that makes you you? (Is it more than your knowledge and personality?) Is having the traditional body necessary to being human? Nevertheless, if you accept the above premises, it could be done. Having made the leap to new hardware for yourself, many staggering options open up:

No death. You back yourself up. You get new hardware as needed.

Turn up the clock speed. Goodbye, millisecond-speed neurons; hello, nanosecondspeed electronics.

Choose space-friendly hardware. Goodbye, Earth; hello, galaxy. (2002: 166)

The images of downloading and uploading information from the human brain to a machine and "jacking into the system" are reminiscent of movies such as Johnny Mnemonic and The Matrix trilogy (inspired from the well-known novels by William 
Gibson, Neuromancer and Mona Lisa Overdrive). The tone adopted is casual and the author, Warren Robinett - who is a video game and virtual reality specialist - addresses the reader directly, even dynamically, with the use of the imperative ("Imagine...") and a series of questions. Popular culture references supply the reader with the ability to understand an otherwise highly technical concept in the field of artificial intelligence. Because we are in the Visionary Project section of the report, the extrapolation mode allows the author to abandon the 'objective' discourse of scientific observation and slip into a less formal type of narrative. One can speculate that presenting such ideas in a light, humorous mode also allows the author to distance himself from possible peer ridicule, since it is only wild speculation for the sake of exposing the limitless possibilities of converging technologies, not a research project.

\section{A picture is worth a thousand words}

One salient feature of 'nanoliterature' for the layman is an abundant use of illustrations in an attempt to give tangible proof of the nanoworld that is otherwise, obviously, quite impossible to comprehend. Interestingly, certain images, obtained using the scanning tunneling microscope, have become emblematic of nanoscience/technology research since the 1990s, and used abundantly in the press both specialized and non-specialized, including one of our objects of study, Scientific American two of which are the following:

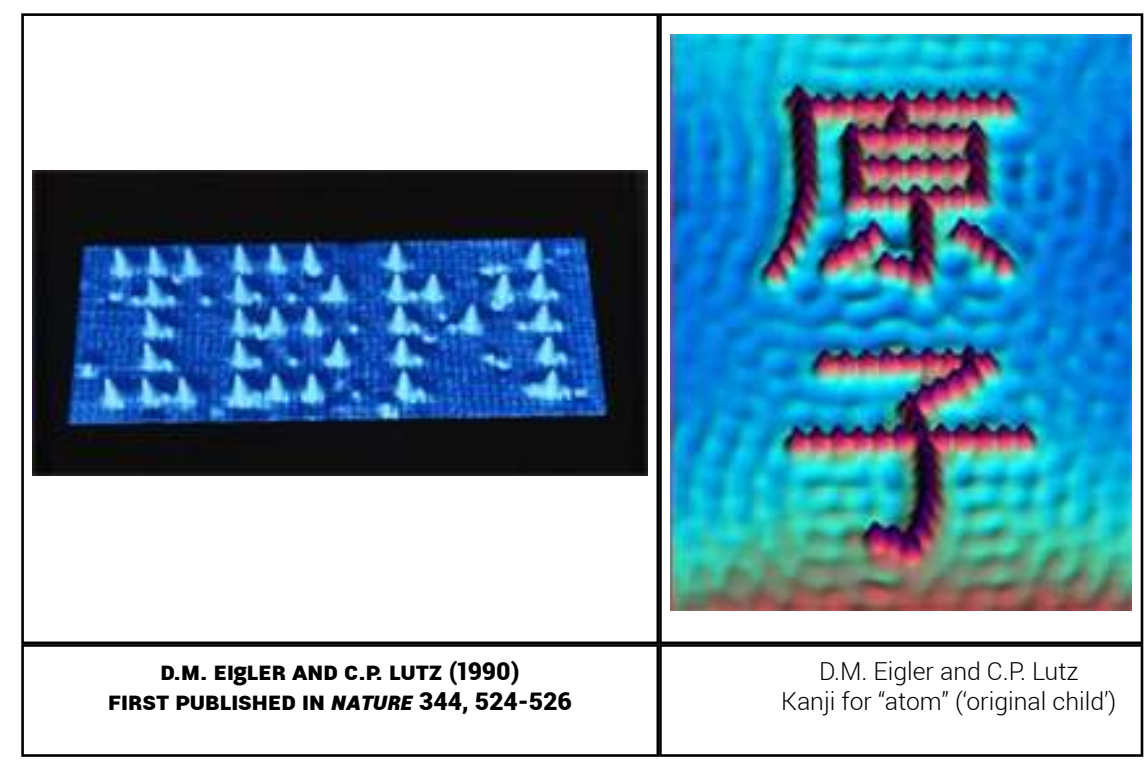

Source: STM Image Gallery, http://www.almaden.ibm.com

Although seemingly "playful" in nature, these images were used to demonstrate how atoms could be moved to form artificial constructions and then be recorded. Obviously this breakthrough proved important in the promotion of the nanorevolution as scientists in various fields then used the STM to show man's growing power in the control of subatomic structures both to other scientists and to the public, essential as we noted earlier in obtaining funds for further research. Government investment in, and promotion of, nanotechnology is apparent in a recent exhibit at the U.S. Patent and Trademark Museum (Alexandria, Virginia) entitled "The Art of Invention - the

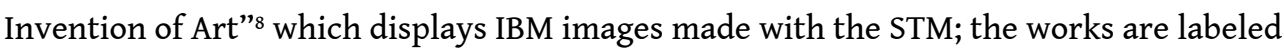


"the world's tiniest art on display" and "nanotechnology at its finest." These same images are reproduced in the Scientific American special issue and in the National Nanotechnology Initiative brochures.

Another noteworthy "iconic" image used to illustrate advances in nanoresearch is that of the quantum corral which appears repeatedly in articles seeking to explain subatomic structures to a lay public:

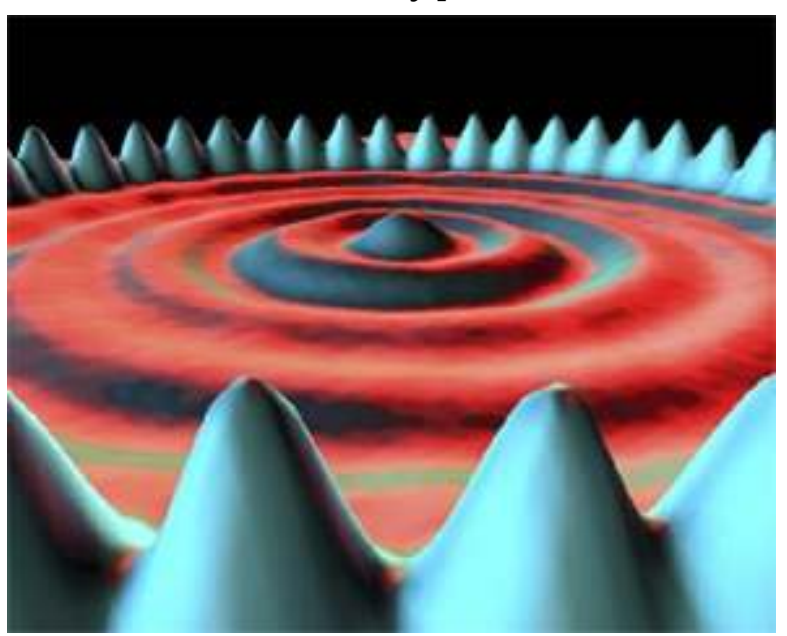

M.F. Crommie, C.P. Lutz and D.M. Eigler

First published in Science 262, 218-220 (1993)

Source: STM Image Gallery, http://www.almaden.ibm.com

For example the image is reproduced in Nanotechnology: Shaping the World Atom by Atom with the caption "the wave nature of electrons becomes visible to the naked eye." The blue spikes of the corral-like structure are "a ring of 48 iron atoms positioned with the same STM used to image them." (1) This image is, however, of particular interest because of the basic questions it raises about the frontiers between presentation and representations of nanostructures, an emerging field of artistic expression promoted by the website nanoart21.org which now organizes an annual online contest for nanoart creations. While early contributions (prior to 2006) primarily consisted of actual STM imaging with some Photoshop enhancements, current entries include original artwork integrating STM imaging into other imagined landscapes:

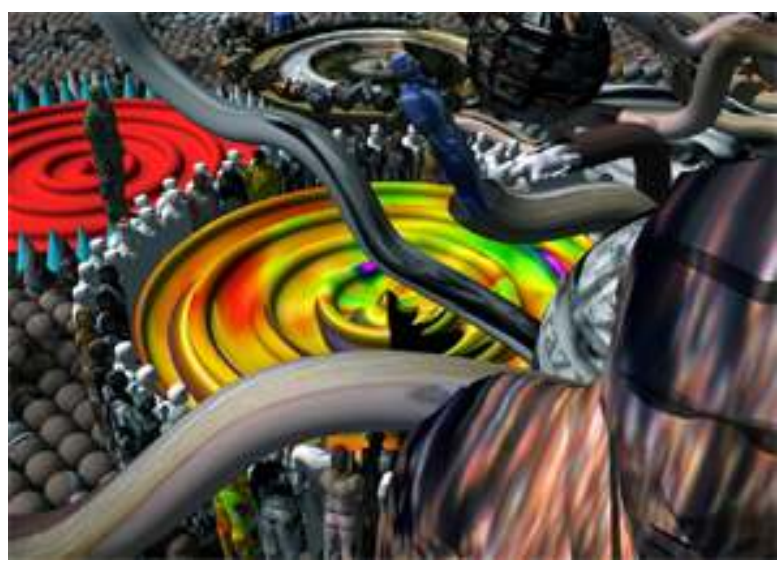

Eigler's Eyes 2, Chris Robinson ${ }^{9}$

Source: http://nanoart21.org 
Departing from the quantum corral image to create an artistic commentary on the human implications of nanosciences (the 'corral' atoms have been replaced by humanlike figures around the yellow circle in the center), close examination shows the composite use of other nanoimagery such as nano carbon tubes (snake-like lines running diagonally, two of which are spitting out human figures on the right-hand side) and "buckyballs" (upper right-hand side). But what has drawn our attention to this particular nanoart piece is the artist's explanatory caption:

This is the second of a series of digital drawings parodying an iconic image in nanotechnology (Quantum Corral, STM image of iron on copper) by IBM scientist Don Eigler. The original image shows Eigler's use of Scanning Tunneling Microscopy (STM) to arrange 48 iron atoms into a ring in order to 'corral' some surface state electrons and force them into quantum states and the resulting electron wave. The image is highly altered to provide convenient access to select information, but also deceives. This artwork explores alternatives to the original image and asks how we note and perceive truth - some of the surface imagery is accurate to this scale, some is not. (my italics)

What is to be understood here is that the STM image of a "nanoreality," presented in those terms in all other places where it has been reproduced for didactic purposes, constitutes in fact a 'liberal' assembly of (nano)elements to make a meaningful representation. This hints at an educational strategy rather than a purely scientific one: what counts is ensuring that the viewer grasps a concept and perhaps marvels at the wonders of the micro-cosmos, even if it is at the expense of scientific accuracy. Robinson questions the purpose of such "convenient access to select information" and how it may impact societal response to technologies of the future. Eigler's Eyes 2 begs the question: Are the human figures (which replace the blue spike atoms of the original image) also being "pushed around" by the invisible hand of science and led to believe in a truth that may not exist?

Pictorial representation of the converging technologies revolution illustrates another dimension of artistic extrapolation in showing the invisible, or in this particular case in seeking to make visual that which does not yet exist. The Converging Technologies for Improving Human Performance report exhibits such creativity, as for example these logolike drawings that supposedly embody the spirit of the NBIC promise of the future:

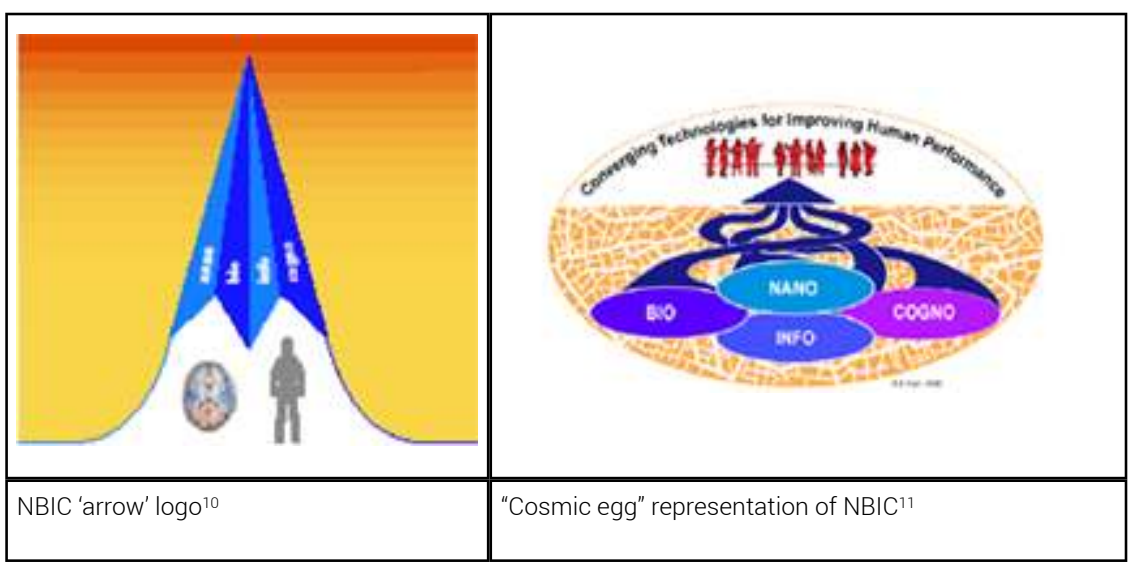

Both images share an emphasis on the ascendant nature of converging technologies and the direct connection between this ascendancy and its effects on humankind. At the same time, however, the objects in each image are presented in opposite order: the 
image on the left departs from a human brain and a human figure and rises through the arrow structure composed of the four component technologies to achieve some superior (but non-visualized) state; the image on the right departs from a cellular-like matter from which the component technologies spring to combine and converge on a group of human figures. One emphasizes benefits for the individual human, the other the benefits for humanity; both suggest the 'natural' aspect of converging technologies, since they both represent the body or body parts as the matter from which the NBIC future will emerge. And finally, both embody the "bottom up" nature of the nanorevolution (as opposed to the current "top down" methods of production).

\section{From science narrative to science fiction: the Transhumanist perspective}

This study of the nanorevolution would not be complete without a brief discussion of the Transhumanist movement which is so intricately linked to American involvement in the global race for the control of nanotechnology. One important link originates with scientists like K. Eric Drexler and Ray Kurzweil mentioned earlier in this paper, who participated in the founding of the Transhumanist movement and have contributed actively to its promotion through their publications; to be noted as well that "futurist" James Canton, the head of San Francisco-based think tank Institute for Global Futures, and William S. Bainbridge, professor of sociology and contributing editor for numerous government publications on converging technologies associated with transhumanism. Media-wise the transhumanist movement has contributed greatly to the vulgarization of the nanorevolution through the creation and development of its official online publication The Journal of Evolution and Technology, and through the spread of transhumanist thought through other media such as the Internet and singularityaware science fiction novels.

The term "transhumanist" seems to have first been used by biologist Julian Huxley (Aldous Huxley's brother) in 1927, in his work Religion Without Revelation in which he wrote:

The human species can, if it wishes, transcend itself - not just sporadically, an individual here in one way, an individual there in another way - but in its entirety, as humanity. We need a name for this new belief. Perhaps transhumanism will serve: man remaining man, but transcending himself, by realizing new possibilities of and for his human nature. (Huxley in Bostrom, 6)

Later in the $20^{\text {th }}$ century, transhumanist interests such as life extension, cryonics (freezing the dead to revive them at a later date), or space colonization were mainly the subject of science fiction novels by Isaac Asimov (his Foundation series) or Arthur C. Clark (his memorable smart computer H.A.L. in 2001, A Space Odyssey), among others. As Nick Bostrom points out in his seminal article "A History of Transhumanist Thought", (2005) until the 1990s transhumanists were "disparate groups of people with futuristic ideas"; the Internet helped facilitate a "meeting of the minds", (2005: 12) which eventually matured into the modern transhumanist movement now represented by the World Transhumanist Association. The WTA, founded by Nick Bostrom (who has a Ph. D. in philosophy) and David Pearce in 1998, "advocates the ethical use of technology to expand human capacities [and supports] the development of and access to new technologies that enable everyone to enjoy better minds, better bodies and 
better lives" (website declaration). Although the movement remains marginal - only about 5,000 members worldwide - they are actively visible in the media attention given to the nanorevolution: as we have seen, K. Eric Drexler was invited to write an article for the special issue of Scientific American despite the fact that "the mainstream nanotechnology community has sought to distance itself from Drexler's claims" that nanotechnology will one day become "an assembler-based, near-universal, construction technology." (Bostrom, 9)

41 As modern transhumanism has developed, discussions of not only the positive aspects of converging technologies but also of their threatening aspects have grown: in his 2002 article "Existential Risks: Analyzing Human Extinction Scenarios and Related Hazards" Bostrom introduced the concept of "existential risk," that is the adverse effects of transforming technologies which could lead to the annihilation of Earth and all intelligent life. One result has been the emergence of what is now called "democratic transhumanism," coined by James Hughes in his 2004 work Citizen Cyborg: Why Democratic Societies Must Respond to the Redesigned Human of the Future. Democratic transhumanism diverges from the earlier form of transhumanism (called "extropian transhumanism") in that it demands a much bigger role for government in regulating the safety of new technologies and in ensuring that the benefits will be available to everyone, not just a wealthy, 'techno-elite.'

In conclusion it can be said that the nanorevolution has enjoyed widespread media coverage at all levels, ranging from the highly specialized press to science fiction; government involvement in nanotechnology has contributed, as well, to making it a "buzz word" in universities and in the R\&D divisions of major American firms. As mentioned earlier, continuing massive publications in the specific fields related to nanoscience applications, especially in crucial medical areas such as cancer treatment, or in military applications linked to the post-911 global war on terror will probably keep the nanorevolution in the press for years to come. Yet such pragmatic worries that is seeking to "cash in" on nanotechnology as quickly as possible - has resulted in the "dumbing down" of complex biological and chemical concepts to ward off the fears of bio-conservative groups and possible consumer backlash to nano-commodities of the (posthuman) future. Thus perhaps we are to expect in the future a penchant for a more politically and economically oriented discourse of the nanoworld at the expense of a didactic approach to this highly specialized field of science.

\section{BIBLIOGRAPHIE}

\section{Sources cited}

Alivisatos, A. Paul. "Less is More in Medicine" in Nanotech: The Science of the Small Gets Down to Business. Scientific American special issue, September 2001, 67-73. 
Amato, Ivan. Nanotechnology: Shaping the World Atom by Atom. Washington, D.C.: National Science and Technology Council (downloaded from the National Nanotechology Initiative website http:// www.nano.gov, 28 June).

Bostrom, Nick. "Existential Risks: Analyzing Human Extinction Scenarios and Related Hazards" in Journal of Evolution and Technology 9 (1) March 2002.

Bostrom, Nick. "A History of Transhumanist Thought" in Journal of Evolution and Technology 14 (1) April 2005, 1-25.

Drexler, K. Eric. Engines of Creation: The Coming Era of Nanotechnology. New York: Anchor Books, 1986.

Drexler, K. Eric. "Machine-Phase Nanotechnology" in Nanotech: The Science of the Small Gets Down to Business. Scientific American special issue, September 2001, 74-75.

Hughes, James. Citizen Cyborg: Why Democratic Societies Must Respond to the Redesigned Human of the Future. Cambridge, Massachusetts: Westview Press, 2004.

Matlack, Carol and John Carey. "Nano, Nano, On the Wall...: L'Oréal and others are betting big on products with microparticles.” http://www.businessweek.com downloaded 16 January.

Porter, Charlotte. The Eagle's Nest : Natural History and American Ideas, 1812-1842. Tuscaloosa: University of Alabama Press, 1986.

Roco, Mihail and William Bainbridge, eds. Converging Technologies for Improving Human Performance. Washington, D.C.: National Science Foundation and Department of Commerce report, June 2002.

Schmidt, Stanley. The Coming Convergence: The Surprising Ways Diverse Technologies Interact to Shape Our World and Change the Future. New York: Prometheus Books, 2008.

Stix, Gary. "Little Big Science" in Nanotech: The Science of the Small Gets Down to Business. Scientific American special issue, September 2001, 32-37.

Thomas, Jim. "Future Perfect?" in The Ecologist, May 2003, 33-39.

Whitesides, George and Christopher Love. "The Art of Building Small” in Nanotech: The Science of the Small Gets Down to Business. Scientific American special issue, September 2001, 39-62.

\section{Website sources}

http://blogs.zdnet.com/emergingtech

http://jetpress.org (Journal of Evolution and Technology)

http://nanoart21.org (site which organizes online art contests)

http://transhumanism.org (official website of the World Transhumanist Association)

http://www.almaden.ibm.com (STM Image Gallery)

http://www.nanophonics.org.uk

\section{NOTES}

1. The NNI, a coordinating body of twenty-six departments and agencies of the U.S. government, was created in 2000 by the Clinton administration to boost funding for research in nanotechnology and to "ensure U.S. leadership in nanotechnology innovation"; it is part of the National Science and Technology Council, also established by President Clinton in 1993, as a 
means of "coordinating science, space and technology policies across the federal government." (framing letter, Nanotechnology: Shaping the World Atom by Atom)

2. The National Science Foundation is an independent federal agency created by Congress in 1950 "to promote the progress of science; to advance the national health, prosperity and welfare; to secure the national defense." The NSF has an annual budget of over 6 billion dollars and finances 20 percent of university research in fields such as mathematics, computer science and the social sciences. (Source: NSF official website www.nsf.gov, consulted 7/11/08.

3. The NSF report overview, by M. Roco and W.S. Bainbridge defines the holistic approach in these terms: "The hallmark of the Renaissance was its holistic quality, as all fields of art, engineering, science, and culture shared the same exciting spirit and many of the same intellectual principles. A creative individual, schooled in multiple arts, might be a painter one day, an engineer the next, and a writer the day after that. However, as the centuries passed, the holism of the Renaissance gave way to specialization and intellectual fragmentation. Today, with the scientific work of recent decades showing us at a deeper level the fundamental unity of natural organization, it is time to rekindle the spirit of the Renaissance, returning to the holistic perspective on a higher level, with a new set of principles and theories." (3)

4. The American government's enthusiasm seems to be waning if one is to believe the Foresight Institute website which states that federal spending on nanotechnology research in 2005 dropped to $\$ 5.42$ per capita in the United States, behind South Korea ( $\$ 5.64$ per capita), Japan ( $\$ 6.30$ per capita) and now China ( $\$ 611$ million annually); budgets for 2006 and 2007 are on the decrease. Source: www.foresight.org, consulted 7/12/08.

5. To be noted here that despite the sometimes controversial nature of their contributions to the field, K. Eric Drexler and Ray Kurzweil are scientists. Drexler is a graduate of M.I.T., a researcher in nanotechnologies and founder of The Foresight Institute; Kurzweil is also a graduate of M.I.T, a pioneer in speech recognition technology and a specialist in artificial intelligence.

6. Since this incident it is no longer possible to find information on L'Oréal's website about its nanocosmetic research or marketed products. However, a Business Week article dated December 122005 states that the company "says that in 2006 it will introduce cosmetics containing nanoparticles engineered to produce more vivid colors and iridescent or metallic effects" and "to create eye shadow with a hologram-like three-dimensional effect." Source: http:// www.businessweek.com consulted 1/16/08.

7. "Scanning and copying the salient computational methods of a human brain into a neural computer of sufficient capacity is a future example of reverse engineering." Ray Kurzweil's definition on his website http://kurzweilai.net/brain consulted 7/18/08.

8. The exhibit opened August 15, 2007 and was still running at the time this article was written.

9. "Chris Robinson is a visual artist who is interested in the role and meaning of science and technology in contemporary culture and how it assists in and influences decision-making. He is a senior and co-principal investigator on National Science Foundation funded multi-disciplinary research teams investigating the broader impacts, societal implications, and role of images in nanoscience/technology. Robinson teaches 3D and digital imaging in the Department of Art at the University of South Carolina. His work over the years has ranged from the early use of computers in the arts to laser installations, aviation and space development, and complex drawings of digital spaces. Robinson crosses the two cultures and exhibits, writes, and presents at national and international venues and conferences in the arts and sciences." (Source: http:// nanoart21.org, image and text downloaded 7/15/08).

10. The image is described in the report in these terms: "The arrow suggests the combined role of nanotechnology, biotechnology, information technology in accelerating advancement of mental, physical, and overall human performance." (inside cover, NSF report).

11. This image, by R.E. Horn is described in the following terms: "This picture symbolizes the confluence of technologies that now offers the promise of improving human lives in many ways, 
and the realignment of traditional disciplinary boundaries that will be needed to realize this potential. New and more direct pathways towards human goals are envisioned in working habits, in economic activity, and in the humanities." (NSF report, vii).

\section{RÉSUMÉS}

Les quatre dernières années ont vu un intérêt soutenu pour les nanotechnologies de la part du gouvernement américain, à la recherche d'applications pratiques des nanosciences qui amèneront théoriquement à une transformation sociétale et humaine profonde dans les décennies à venir. Cet article tente de démontrer de quelle(s) manière(s) la "nanorévolution » est décrite dans différents types de supports médiatisés: un numéro spécial de la revue Scientific American en septembre 2001; le rapport de la National Science Foundation (agence fédérale américaine) publié en juin 2002; des ouvrages et articles publiés par des membres de la World Transhumanist Association; et enfin des images de nanoparticles «mises en scène » sur des sites Internet dédiés au « nanoart ».

Recent interest, on the part of the American government, for the practical applications of nanosciences, has led to the concept of a "nanorevolution" that will transform society and humanity itself in the decades to come. This paper attempts to shed light on how this nanorevolution is depicted in different mediatized forms: a special issue of Scientific American published in September 2001; the National Science Foundation publication in June 2002; various books and articles by the World Transhumanist Association; and Internet sites dedicated to artwork which "stage" nanoparticles of different types for both didactic and creative purposes.

\section{INDEX}

Keywords : nanotechnology, nanosciences, mediatized discourse, scientific vulgurization, science narrative and science fiction, transhumanism, cultural intertextuality

Mots-clés : nanotechnologie, nanosciences, discours médiatique, vulgarisation scientifique, récit de science et science fiction, transhumanisme, intertextualité

\section{AUTEUR}

\section{DONNA ANDRÉOLLE}

Université Stendhal-Grenoble 3

CEMRA 